\title{
The Problem of the "Un-omitted" Spouse Under Section 2-301 of the Uniform Probate Code
}

When a testator marries after the execution of his will and then dies without amending his will to include a gift for his new spouse, two different inferences are possible. He may simply have forgotten to change his will, or he may have intended to omit his surviving spouse. ${ }^{1}$ Although it is a truism of probate law that courts cannot make wills for people, ${ }^{2}$ courts faced with the omitted-spouse problem have found it necessary to circumvent this interdiction: in order to prevent the unintentional disinheritance of the surviving spouse, courts have developed the doctrine of implied revocation by change in domestic circumstances. This doctrine allows a court to revoke an antenuptial will, either entirely or in part, in order to give a share of the estate to the surviving spouse. ${ }^{3}$ Section 2-301 of the Uniform Probate Code (U.P.C. or the Code) codifies a version of this rule. ${ }^{4}$ Under section 2-301, a surviving spouse who married the testator after his will was executed and is not "provided for" in his will is entitled to receive an intestate share of the estate, ${ }^{5}$ unless the testator either expressly disinher-

1 See M. Rheinstein \& M. Glendon, The Law of Decedents' Estates 267-68 (1971).

2 See 4 W. Bowe \& D. Parker, Page on the Law of Wills $\$ 30.7$, at 40 (rev. ed. 1961).

s See, e.g., Thomas Atkinson, Handbook of the Law of Wills $\$ 85$ (2d ed. 1953); 2 W. Bowe \& D. PARKER, supra note $2, \S 21.86$. Both the common law doctrine of implied revocation by change in domestic circumstances and modern omitted-spouse statutes are discussed infra notes $12-28$ and accompanying text.

- UnIF. Probate Code $\$ 2-301$ (a) (1983) [hereinafter cited without cross-reference as U.P.C.] provides:

If a testator fails to provide by will for his surviving spouse who married the testator after the execution of the will, the omitted spouse shall receive the same share of the estate he would have received if the decedent left no will unless it appears from the will that the omission was intentional or the testator provided for the spouse by transfer outside the will and the intent that the transfer be in lieu of a testamentary provision is shown by statements of the testator or from the amount of the transfer or other evidence.

At least 14 states have adopted the U.P.C. in its entirety. See 8 U.L.A. 1 (1983).

s The omitted spouse's intestate share is described in U.P.C. § 2-102:

(1) if there is no surviving issue or parent of the decedent, the entire intestate estate;

(2) if there is no surviving issue but the decedent is survived by a parent or parents, the first $[\$ 50,000]$, plus one-half of the balance of the intestate estate; 
ited the spouse in the will or made an extratestamentary provision for the spouse that he intended to be in lieu of a provision by will. This comment discusses the circumstances in which a surviving spouse who is a beneficiary of an antenuptial will (the "mentioned" spouse) has been "provided for" within the meaning of section 2-301. In the more common case, where an antenuptial will makes no mention of the surviving spouse, section 2-301 presumes that the surviving spouse has been omitted because the testator forgot to revise his will before his death. ${ }^{6}$ Where the antenuptial will does contain a devise ${ }^{7}$ to the surviving spouse, however, it is more troublesome to presume that the testator unintentionally failed to increase the devise in light of the change in his personal life.

Two state supreme courts have considered the problem of applying section 2-301 (or an omitted-spouse statute modeled on that provision) when the petitioning spouse is a beneficiary of the antenuptial will. In Estate of Ganier $v$. Estate of Ganier, ${ }^{8}$ the Florida Supreme Court held that a surviving spouse has not been "provided for" within the meaning of the omitted-spouse statute, even though the antenuptial will contains a provision for him, unless the testator executed the antenuptial devise in contemplation of mar-

(3) if there are surviving issue all of whom are issue of the surviving spouse also, the first $[\$ 50,000]$, plus one-half of the balance of the intestate estate;

(4) if there are surviving issue one or more of whom are not issue of the surviving spouse, one-half of the intestate estate.

Section 3-902 describes the abatement of the will's provisions necessitated by the spouse taking an intestate share. Id. $\S 3-902$.

If a surviving spouse is not covered by section $2-301$, he may choose to renounce the will and take an elective share of one-third of the "augmented estate" under section 2-201. Id. $\S 2-201$ (a). The "augmented estate" is defined generally to include the decedent's net probate estate increased by (1) the value of certain lifetime transfers of property by the decedent during marriage to donees other than the surviving spouse, id. $\$ 2-202(1)$; and (2) the value of all property owned by the surviving spouse at the decedent's death and certain lifetime transfers of property by the surviving spouse during marriage to donees other than the decedent, to the extent that the owned or transferred property is derived from the decedent, id. § 2-202(2). For detailed descriptions of the Code's elective-share provisions, see Kossow, Probate Law and the Uniform Code: "One for the Money", 61 GEo. L.J. 1357, 138893 (1973); Kurtz, The Augmented Estate Concept Under the Uniform Probate Code: In Search of an Equitable Elective Share, 62 Iowa L. REv. 981, 1011-61 (1977).

- See infra text accompanying notes 67-68.

Traditionally, the term "devise" referred to a testamentary transfer of real property, and the term "bequest" referred to a testamentary transfer of personal property. See J. Dukeminier \& S. Johanson, Wills, Trusts, and Estates 36 (3d ed. 1984). Within the Code, however, the word "devise" is defined to include both kinds of transfers. U.P.C. $\S 1-201(7)$. This comment follows the Code's usage.

s 418 So. 2d 256 (Fla. 1982). 
riage to that person. ${ }^{9}$ The Utah Supreme Court, in Estate of Christensen $v$. Christensen ${ }^{10}$ refused to read a contemplation-of-marriage requirement into section 2-301 and instead concluded that the petitioning spouse mentioned in an antenuptial will has the burden of showing that the devise "could not reasonably represent th[e] testator's effort 'to provide by will for his surviving spouse." "11

Part I of this comment first examines the common law and statutory treatment of the problem of the surviving spouse who was "mentioned" in an antenuptial will and then examines current interpretations of section 2-301. Part II analyzes section 2-301 and other provisions of the Code in order to determine the appropriate treatment of "mentioned" spouses under section 2-301. The comment argues that because section 2-301 is a gap-filling rule designed to effectuate the testator's probable intent, courts should focus on whether the testator in fact considered the relationship between his marriage and his old will and intended his surviving spouse to receive only what was devised in the antenuptial will. Part III proposes procedural standards to be used in implementing this "testator's intent" approach. Through proper allocation of the burden of proof, probate courts will be able to handle most "mention cases" quickly and efficiently. For the small class of cases in which the application of this approach would require courts to consider evidence extrinsic to the will, the comment recommends the admission of such evidence (under a clear-and-convincing-evidence standard) when it is relevant to the inquiry into the testator's intent.

\section{BACKGROUND}

\section{A. Common Law and Statutory Treatment of Omitted Spouses}

At common law, a woman's marriage revoked her antenuptial will under the general rule that married women lacked testamentary capacity. ${ }^{12}$ A man's antenuptial will, however, was revoked only by the birth of legitimate issue; the wife was not an heir of her husband (and therefore could not benefit from revocation) and

- Id. at 260.

${ }^{10} 655$ P.2d 646 (Utah 1982).

${ }_{11}$ Id. at 649-50 (quoting UTAH CODE ANN. \$ 75-2-301 (1978), which is essentially identical to U.P.C. $\$ 2-301)$.

${ }^{12}$ See T. Atrinson, supra note $3, \S 85$, at 426; M. Rheinstein \& M. Glendon, supra note 1 , at $268-69$. 
had her right to dower regardless of what the will provided..$^{13}$ In the eighteenth and early nineteenth centuries, there was considerable controversy over the theoretical justification for the doctrine of implied revocation by change in domestic circumstances. ${ }^{14}$ The ecclesiastical courts ${ }^{15}$ and some common law judges ${ }^{16}$ held that this doctrine created a rebuttable presumption of revocation; the presumption was raised on the theory that the testator would have wanted his will to be revoked where there had been a change in his domestic circumstances. These courts would admit extrinsic evidence to rebut the presumption of revocation. ${ }^{17}$ Most common law courts, however, concluded that the implied-revocation doctrine was an irrebuttable rule of law, which operated regardless of the testator's intent, because of a "tacit condition annexed to the will itself at the time of making it, that the [testator] does not then intend that it should take effect if there should be a total change in the situation of his family." the English courts were in agreement on the latter approach and held that the will was revoked regardless of the testator's intent. ${ }^{19}$

Modern omitted-spouse statutes have modified the common law doctrine in several respects. ${ }^{20}$ Perhaps the most significant

1s See T. Atkinson, supra note 3 , $\$ 85$, at $424,428-29$; M. Rheinstein \& M. Glendon, supra note 1 , at 269 .

14 See R. Wellman, L. Waggoner \& O. Browder, Palmer's Cases and Materials on Trusts And Succession 261 (4th ed. 1983); Graunke \& Beuscher, The Doctrine of Implied Revocation of Wills by Reason of Change in Domestic Relations of the Testator, 5 WIS. L. REv. 387, 393-94 (1930).

${ }_{13}$ See, e.g., Fox v. Marston, 1 Curteis Eccl. Rep. 494, 499, 505 (Prerog. Ct. Canterbury 1837); Johnson v. Wells, 2 Haggard Eccl. Rep. 561, 564 (Prerog. Ct. Canterbury 1829); Talbot v. Talbot, 1 Haggard Eccl. Rep. 705, 711 (Prerog. Ct. Canterbury 1828).

${ }_{16}$ Lord Mansfield and Lord Buller adopted the position that the presumption of revocation is rebuttable, see Brady v. Cubitt, 1 Dougl. 31, 39 (K.B. 1778), but Lord Buller later abandoned this approach, see Doe v. Lancashire, 5 T.R. 49, 61, 101 Eng. Rep. 28, 35-36 (K.B. 1792) ("I entirely concur with my Lord [Kenyon] that no regard is to be paid [to the declarations of the testator].").

${ }^{27}$ See, e.g., Brady v. Cubitt, 1 Dougl. 31, 39-39a (K.B. 1778); Graunke \& Beuscher, supra note 14, at 393.

${ }_{18}$ Doe v. Lancashire, 5 T.R. 49, 58, 101 Eng. Rep. 28, 34 (K.B. 1792) (Lord Kenyon, C.J.); see also Marston v. Roe, 8 Ad. \& E. 14, 60, 112 Eng. Rep. 742, 758 (Ex. Ch. 1838) (Tindal, C.J.) ("the law annexes the tacit condition that subsequent marriage and the birth of a child operates as a revocation"); Doe, 5 T.R. at 63, 101 Eng. Rep. at 36-37 (Grose, J.) ("The law presumes that ... there was a tacit condition annexed to the will, that in [the event of marriage and the subsequent birth of a child] the will should not stand.").

19 See, e.g., Israell v. Rodon, 2 Moore 51, 63-64, 12 Eng. Rep. 922, 926-27 (P.C. 1839); Walker v. Walker, 2 Curteis Eccl. Rep. 854, 854-55 (Prerog. Ct. Canterbury 1841).

${ }^{20}$ For example, the current rule is that marriage alone may be sufficient to revoke the will of either a man or a woman. See, e.g., CAL. Prob. Code $\S 6560$ (West Supp. 1985); Fla. Stat. ANN. § 732.301 (West Supp. 1984); cf. U.P.C. § 2-301(a) (intestate share may be awarded where a surviving spouse married the testator after the execution of the latter's 
change is that the irrebuttable presumption of revocation, triggered by the testator's marriage after the execution of his will, has been replaced by a revocation that operates in more limited circumstances. ${ }^{21}$ The elimination of the irrebuttable presumption forced courts to reexamine the theoretical basis for the presumption of revocation so that they could ascertain the circumstances in which the presumption could be rebutted.

In addressing the special problem of surviving spouses who had received devises in antenuptial wills, most courts have concluded that the proper inquiry under pre-Code omitted-spouse statutes is whether the antenuptial will was executed in contemplation of marriage. ${ }^{22}$ Two different rationales have been offered for this test. California courts have reasoned that by ensuring that the testator, in executing his will, considered the surviving spouse as a spouse, the contemplation-of-marriage requirement advances what they have considered to be the primary purpose of omittedspouse statutes: the protection of the surviving spouse. ${ }^{23}$ An alter-

will). Some jurisdictions have also concluded that the antenuptial will is not revoked entirely, but only as it affects the share of the estate going to the surviving spouse. See, e.g., CAL. Prob. Code $\$ 6560$ (West Supp. 1985); cf. U.P.C. § 2-301(a) (where the testator fails to provide for a surviving spouse who married the testator after the execution of the latter's will, "the omitted spouse shall receive the same share of the estate he would have received if the decedent left no will").

${ }^{21}$ See, e.g., Fla. Stat. AnN. $\$ 732.301$ (West Supp. 1984) (no revocation if provision has been made for, or waived by, the spouse by prenuptial or postnuptial agreement, or if the spouse is provided for in the will, or if the will shows an intent not to provide for the spouse); cf. U.P.C. \$ 2-301(a) (no award of the intestate share if the will shows an intent not to provide for the spouse, or if the spouse is provided for by extratestamentary transfer intended to replace a devise).

${ }_{22}$ See, e.g., Estate of Poisl, 44 Cal. 2d 147, 149-50, 280 P.2d 789, 791-92 (1955); In re Estate of Day, 7 Ill. 2d 348, 354-55, 131 N.E.2d 50, 53 (1955); In re Estate of Mosher, 143 Misc. 149, 156-57, 256 N.Y.S. 235, 245 (Sur. Ct. 1932). A few states have statutes that expressly adopt the contemplation-of-marriage requirement. See, e.g., GA. CoDE ANN. § 53-2-76 (1982).

23 See Estate of Poisl, 44 Cal. 2d 147, 149, 280 P.2d 789, 791-92 (1955); see also In re Estate of Murray, 145 Cal. App. 3d 324, 327, 193 Cal. Rptr. 355, 356 (1983) (the omittedspouse statute "reflects a strong public policy against disinheritance of a surviving spouse, who is not provided for in the premarital will of the testator.") (citation omitted). Some courts and commentators, however, have argued that the purpose of omitted-spouse statutes is not to protect the surviving spouse contrary to the testator's intent, but rather to revoke the will if the testator unintentionally failed to provide for the surviving spouse. See, e.g., Czepiel v. Czepiel, 146 Conn. 439, 442, 151 A.2d 878, 880 (1959) (purpose is not to ensure adequate provision for surviving spouse, but to ensure that contingency of marriage was not overlooked); Comment, In re Estate of Christensen: Utah Rejects Contemplation of Marriage Standard in Omitted Spouse Cases, 1983 UTaH L. Rev. 861, 863-64 (same). This comment will argue that section 2-301 is a rule of construction designed to implement the testator's probable intent, not a rule of law that operates regardless of his actual intent. See infra notes 67-71 and accompanying text. 
native rationale, adopted by New York courts, relies on an imputed-intent theory similar to the one proposed by the old ecclesiastical courts: ${ }^{24}$ if there has been a major change in the testator's domestic circumstances, he would have intended for his will to be revoked unless he had executed his will in contemplation of marriage. ${ }^{25}$

Some courts have rejected the contemplation-of-marriage requirement altogether and have instead adopted a narrow construction of omitted-spouse statutes. ${ }^{26}$ Under this approach, a surviving spouse is considered to have been "provided for" within the meaning of the omitted-spouse statute whenever the antenuptial will contains a devise to him. ${ }^{27}$ Although these courts have not articulated a clear rationale for this test, it is apparently based on the view that because omitted-spouse statutes restrict testamentary freedom, they should be narrowly construed. ${ }^{28}$

\section{B. Current Interpretations of Section 2-301}

Section 2-301 differs from the common law and some other omitted-spouse statutes in several respects. The most important among these is that section 2-301 creates a rule according to which the surviving spouse receives the intestate share only if he marries the testator after the execution of a will that does not "provide

24 See supra note 15 and accompanying text.

${ }^{25}$ See, e.g., In re Simon, 232 A.D. 214, 215, 249 N.Y.S. 683, 685-86, aff'd mem. sub nom. In re Reiss, 257 N.Y. 539, 178 N.E. 785 (1931); In re Estate of Mosher, 143 Misc. 149, 152, 256 N.Y.S. 235, 239 (Sur. Ct. 1932). In 1967, New York repealed its omitted-spouse provision for all wills executed after September 1, 1930. A surviving spouse, however, may still renounce the will and take a one-third elective share of the probate estate. See N.Y. EsT. Powers \& Trusts LaW \$§ 5-1.1(a), 5-1.3(a) (McKinney 1981). All spouses claiming to be omitted from wills executed before September 1, 1930, will receive the intestate share "unless provision was made for the surviving spouse by antenuptial agreement in writing." Id. $\S 5-1.3(a)$.

${ }^{28}$ See In re Estate of Appenfelder, 99 Cal. App. 330, 335, 278 P. 473, 476 (1929), overruled, Estate of Poisl, 44 Cal. 2d 147, 150, 280 P.2d 789, 792 (1955); In re Estate of Steele, 45 Wash. 2d 58, 61, 273 P.2d 235, 236 (1954).

${ }_{27}$ See In re Estate of Appenfelder, 99 Cal. App. 330, 333, 278 P. 473, 474-76 (1929), overruled, Estate of Poisl, 44 Cal. 2d 147, 150, 280 P.2d 789, 792 (1955); In re Estate of Steele, 45 Wash. 2d 58, 61, 273 P.2d 235, 236 (1954).

${ }^{28}$ Cf. In re Estate of Adler, 52 Wash. 539, 548-49, 100 P. 1019, 1023 (1909) ("[T]he grounds upon which wills are or may be revoked are statutory, [but] it is also the rule that revocation of wills by implication of law are not favored."); Estate of Ganier, 402 So. 2d 418, 421 (Fla. Dist. Ct. App. 1981) ("[Omitted spouse statutes] are in derogation of the general power to make a will and should be strictly construed. No exception should be extended to include a class not clearly comprehended in the statute[s].") (citation omitted), rev'd sub nom. Estate of Ganier v. Estate of Ganier, 418 So. 2d 256 (Fla. 1982). 
for" him. ${ }^{29}$ As a result, courts have had to consider whether section 2-301 requires a special test for surviving spouses who received devises in antenuptial wills.

1. The Contemplation-of-Marriage Requirement. In Estate of Ganier v. Estate of Ganier, ${ }^{30}$ the Florida Supreme Court held that an omitted-spouse statute modeled on section 2-301 included the contemplation-of-marriage requirement, even though the statute did not expressly provide for it. ${ }^{31}$ In Ganier, the testator, Emma Kennedy, and the petitioner, Frederic Ganier, had been close friends since 1973. In 1977, Mrs. Kennedy executed a will, devising her bank accounts to $\mathrm{Mr}$. Ganier and the residue of her estate to relatives. The couple married in 1978, and Mrs. Kennedy died six months later. ${ }^{32}$

In denying Mr. Ganier's claim for an intestate share under the omitted-spouse statute,$^{33}$ the intermediate appellate court adopted a narrow construction of the statute. ${ }^{34}$ Because the statute neither contains a contemplation-of-marriage standard nor explains how a party might demonstrate that the antenuptial devise was executed in contemplation of marriage, the court rejected $\mathrm{Mr}$. Ganier's argument that a contemplation-of-marriage test should be read into the statute. $^{35}$ The court instead interpreted the statute literally and held that any devise in the antenuptial will is sufficient to foreclose

20 U.P.C. § 2-301(a). Another respect in which section 2-301(a) differs is that, unlike the common law and most omitted-spouse statutes, see R. WELlMan, L. WAGGONER \& O. BrowDER, supra note 14, at 261-62, it does not revoke the entire will, but merely provides that the surviving spouse is entitled to the intestate share, U.P.C. § 2-301(a).

so 418 So. 2d 256 (Fla. 1982).

31 Id. at 260 .

32 Id. at 257.

s3 Fla. Stat. Ann. $\$ 732.301$ (West Supp. 1984) provides:

When a person marries after making a will and the spouse survives the testator, the surviving spouse shall receive a share in the estate of the testator equal in value to that which the surviving spouse would have received if the testator had died intestate, unless:

(1) Provision has been made for, or waived by, the spouse by prenuptial or postnuptial agreement;

(2) The spouse is provided for in the will; or

(3) The will discloses an intention not to make provision for the spouse.

Section 732.301, though not identical to U.P.C. $\$ 2-301$ (quoted supra note 4), is modeled on that provision. See 8 U.L.A. I (1983). The only difference in wording that may affect the outcome of a case relates to extratestamentary provision. Compare Fla. Stat. AnN. $\S 732.301(1)$ (West Supp. 1984) (quoted supra) with U.P.C. § 2-301(a) (no omission if "the testator provided for the spouse by transfer outside the will and the intent that the transfer be in lieu of a testamentary provision is shown").

34 Estate of Ganier, 402 So. 2d 418, 420-21 (Fla. Dist. Ct. App. 1981), rev'd sub nom. Estate of Ganier v. Estate of Ganier, 418 So. 2d 256 (Fla. 1982).

${ }^{35}$ Id. at 421 \& n.3. 
an award of the intestate share.$^{36}$ The dissent argued that the majority's standard allowed a surviving spouse to be effectively disinherited by a minimal devise made in a will executed long before marriage. ${ }^{37}$ The court responded, however, that the statutory elective-share provision, ${ }^{38}$ which allows any surviving spouse to reject the testamentary devise and take a thirty-percent share of the net estate ${ }^{39}$ is the appropriate remedy for cases of "effective" disinheritance. ${ }^{40}$

The Florida Supreme Court rejected the appellate court's narrow interpretation of the omitted-spouse statute and concluded that the dispositive inquiry is whether the testator contemplated marriage to the devisee at the time the wiil was executed.11 The court offered two arguments to support its interpretation of the statute. First, after reviewing the statute's history, the court found that the state legislature, in modifying the common law rule, had not intended to "eliminat[e] the 'in contemplation of marriage' requirement in circumstances where the will provides for the surviving spouse, but was not made with the understanding that it was for the individual as a surviving spouse." ${ }^{12}$ The court asserted that the contemplation-of-marriage requirement is in fact codified in the three statutory exceptions to the omitted-spouse statute: (1)

${ }^{38}$ Id. at 420-21. A few courts have adopted a similar interpretation of other omittedspouse statutes. See supra notes $26-28$ and accompanying text.

${ }^{37}$ While it is true as the majority suggests, that [the omitted-spouse statute] prevents a surviving spouse to whom a small bequest is given in the will from being "disinherited" because he or she may choose to take an elective share, this is small consolation to the spouse who would otherwise take the entire estate as would be the case where the decedent had no lineal descendants.

Estate of Ganier, 402 So. 2d 418, 424 (Fla. Dist. Ct. App. 1981) (Upchurch, J., dissenting) (citations omitted), rev'd sub nom. Estate of Ganier v. Estate of Ganier, 418 So. 2d 256 (Fla. 1982).

sa Fla. Stat. AnN. § 732.201 (West 1976).

${ }^{39}$ The elective share shall consist of an amount equal to 30 percent of the fair market value, on the date of death, of all assets referred to in [\$] 732.206, computed after deducting from the total value of the assets: (1) All valid claims against the estate paid or payable from the estate; and (2) All mortgages, liens, or security interests on the assets.

Fla. Stat. Ann. § 732.207 (West Supp. 1984). Fla. Stat. Ann. § 732.206 (West 1976) provides that "[t] he elective share shall be computed by taking into account all property of the decedent wherever located that is subject to administration except real property not located in Florida." The U.P.C.'s elective-share provision, section 2-201, gives the surviving spouse one-third of the probate estate, augmented by certain lifetime transfers of property by the decedent. See supra note 5.

${ }^{10}$ Estate of Ganier, 402 So. 2d 418, 421-22. (Fla. Dist. Ct. App. 1981), rev'd sub nom. Estate of Ganier v. Estate of Ganier, 418 So. 2d 256 (Fla. 1982).

11 Estate of Ganier v. Estate of Ganier, 418 So. 2d 256, 259-60 (Fla. 1982).

42 Id. at 258-59. 
where a marriage contract provides for the surviving spouse; (2) where the antenuptial will provides for the spouse; or (3) where the will expressly indicates that the testator did not intend to provide for the spouse. ${ }^{43}$ Second, the court reasoned that the contemplation-of-marriage requirement is consistent with what it considered the primary purpose of the statute: to protect the surviving spouse by "assur[ing] that the decedent spouse considered the surviving spouse as a spouse when making his or her will."44

In applying the contemplation-of-marriage requirement, the court required the surviving spouse to bear the burden of showing that the provision was not made in contemplation of marriage, reasoning that any devise to the surviving spouse in the antenuptial will is prima facie a provision within the literal meaning of the statute. ${ }^{45}$ The court also allowed the admission of extrinsic evidence to establish that the testator had not made the devise in contemplation of marriage to the devisee, though such evidence was limited to circumstances existing at the time of the execution of the will. ${ }^{46}$ In Ganier, Mr. Ganier met his burden of proof when he offered uncontradicted testimony that he and Mrs. Kennedy had not discussed marriage until long after she had executed her will. ${ }^{47}$

2. The Equivocal-Intent Approach. In Estate of Christensen $v$. Christensen, ${ }^{48}$ the Utah Supreme Court asserted that the primary purpose of section 2-301 is to effectuate the testator's intent, not to protect the surviving spouse. ${ }^{49}$ Under this interpretation, determining whether the devise in the antenuptial will was executed in contemplation of marriage is simply a first, although potentially dispositive, step in discerning the testator's intent..$^{\text {so }}$

In Christensen, the testator, Clyde Christensen, and the peti-

43 Id. at 259 (citing Fla. Stat. ANn. $\$ 732.301$ (West Supp. 1984)).

44418 So. $2 d$ at 261 (emphasis in original). California courts have adopted the same justification for reading the contemplation-of-marriage requirement into that state's omitted-spouse statute. See supra note 23 and accompanying text.

45418 So. $2 \mathrm{~d}$ at 260.

48 Id. The general rule in cases where the surviving spouse is a beneficiary in the antenuptial will is that only extrinsic evidence of the facts and circumstances at the time the will was executed is admissible. See infra note 108 and accompanying text. This comment, however, proposes that evidence of extrinsic facts and circumstances subsequent to the execution of the will and of the testator's direct declarations of intent should be admitted, under a clear-and-convincing-evidence standard, when this evidence is relevant to the inquiry into the testator's intent. See infra notes 109-17 and accompanying text.

47418 So. $2 \mathrm{~d}$ at 260.

18655 P.2d 646 (Utah 1982).

40 Id. at 649-50.

so Id. at 650 . 
tioner, Virginia Thompson, had been neighbors since 1966. In 1976, Mr. Christensen executed a will devising most of his ten-million-dollar estate to his granddaughter. In codicils executed in 1977 and 1979, he left Ms. Thompson shares of stock later valued at $\$ 436,000$. The couple married in 1980 , and $\mathrm{Mr}$. Christensen died six weeks later. Ms. Thompson argued that Mr. Christensen's devises of stock in the antenuptial codicils did not prevent an award of the intestate share under section 2-301 because (1) these devises were not made in contemplation of marriage and (2) their value was too small in relation to the value of the estate to constitute a testamentary provision for the surviving spouse. ${ }^{51}$ The court disagreed.

Although it recognized that the common law and prior statutes had adopted a contemplation-of-marriage requirement, the Utah Supreme Court refused to read this requirement into section 2-301 because "[i]n a statute so carefully drafted [as section 2301 ], th [e] omission [of a contemplation-of-marriage requirement] must have been deliberate." W2 With contemplation of marriage eliminated as the dispositive inquiry, the court concluded that the petitioning spouse would have to "establish that the testamentary gift specified before the marriage could not reasonably represent th[e] testator's effort 'to provide by will for his surviving spouse." "53 This interpretation of section 2-301 rests on the assumption that section 2-301 is designed to implement the testator's intent. To support this assumption, the court first noted that the commentary to section 2-301 indicates that the section " $r e$ flects the view that the intestate share of the spouse is what the decedent would [have] want[ed] the spouse to have if he had thought about the relationship of his old will to the new situation." "54 In addition, the court asserted that the choice of an intestate share for the omitted spouse indicates that the primary purpose of section 2-301 is to effectuate the testator's intent because "it fairly approximates what the testator would have bequeathed if he had executed a will after the marriage."ss

In determining whether the devise could "reasonably re-

s1 Id. at 648-49.

${ }^{32}$ Id. at 649. This argument assumes that the drafters of section 2-301 had in fact considered the problem of mentioned spouses in writing that provision. For a criticism of this assumption, see infra note 66 and accompanying text.

${ }^{53} 655$ P.2d at 650 (quoting UTAн Code ANN. $§ 75-2-301$ (1978)). Section 75-2-301 is essentially identical to U.P.C. $\S 2-301$.

${ }^{34} 655$ P.2d at 648 (quoting U.P.C. $\S 2-301$ comment).

os 655 P.2d at 650 . 
present th $[\mathrm{e}]$ testator's effort 'to provide by will for his surviving spouse,' " however, the court declined to adopt an approach that focused solely upon the testator's intent. Although recognizing that a testator could not have intended his surviving spouse to receive the intestate share when a smaller devise was made in contemplation of marriage, the court concluded that an inquiry into the testator's intent could not be dispositive in cases where the evidence does not indicate whether the devise was executed in contemplation of marriage: "[the testator] may simply have neglected to amend his will after marriage, or he may have reexamined the will and decided that his previous testamentary gift would adequately provide for his new spouse." ever, that this ambiguity could be resolved by combining the admission of extrinsic evidence relating directly to the testator's intent after the execution of the will with a corresponding allocation of the burden of proof. Rather, the court would determine whether the will had "provided for" the surviving spouse by examining such objective, equitable factors as the amount of the devise (by itself and in comparison with other devises under the will), the timing and duration of the marriage, and the spouse's need. ${ }^{57}$ Although such factors may be useful in discerning what the testator might have wanted his spouse to have, they suggest that the court was more concerned with what the spouse deserved to have, regardless of what the testator actually intended. ${ }^{58}$

ss Id.

s7 Id. The court listed a total of eight nonexclusive factors that should be considered: (1) the alternative takers under the will, (2) the dollar value of the testamentary gift to the surviving spouse, (3) the fraction of the estate represented by that gift, (4) whether comparable gifts were made to other persons, (5) the length of time between execution of the testamentary instrument and the marriage, (6) the duration of the marriage, (7) any inter vivos gifts the testator has made to the surviving spouse, and (8) the separate Id. property and needs of the surviving spouse.

s8 Many of the factors listed by the Christensen court may be useful in determining the testator's intent at the time of, and subsequent to, the execution of the will. For example, a substantial testamentary devise to the surviving spouse, a short period of time between the execution of the will and the marriage, or substantial inter vivos gifts to the surviving spouse might indicate that the testator had considered his marriage at the time the will was executed or had reexamined his will after his marriage and intended it to remain intact. The eighth factor-“"the separate property and needs of the surviving spouse"-and the court's statement that the evidence must show that the testamentary gift "could not reasonably represent th[e] testator's effort 'to provide by will for'" the spouse suggest, however, that these factors should be considered in determining whether the surviving spouse deserved the intestate share, not in discerning the testator's intent either when the will was executed or after the marriage.

Utah appears to be the only American jurisdiction that has adopted this method of 


\section{Analysis of Mentioned Spouses Under Section 2-301}

The courts have developed two different approaches to the problem of "mentioned spouses" under section 2-301. The Florida Supreme Court, in Ganier, read a contemplation-of-marriage requirement into its omitted-spouse statute, thus forbidding inquiry into the testator's post-execution intent. ${ }^{59}$ The Utah Supreme Court, in Christensen, adopted an approach that purports to focus on the testator's intent, but which also includes consideration of whether the surviving spouse deserved the intestate share in cases where the devise was not executed in contemplation of marriage. ${ }^{60}$ Further analysis of section 2-301 and other provisions of the Code will show that neither court's approach carries the inquiry into the testator's intent far enough.

At first glance, section 2-301 appears to offer no help to surviving spouses who are beneficiaries of antenuptial wills. The section states that a surviving spouse is only entitled to the intestate share if the testator "fails to provide by will for his surviving spouse who married the testator after the execution of the will."61 One could read this language to mean that any devise to the surviving spouse in the antenuptial will "provides for" him, thus barring an award of the intestate share under section $2-301 .^{62}$

This interpretation of section 2-301 would be odd, however,

determining whether a surviving spouse has been omitted, but the inquiry is similar to elements of the testator's-family-maintenance system in England. Under the Inheritance (Provision for Family and Dependants) Act, 1975, ch. 63, English courts have the authority to make "reasonable financial provision" for certain dependents, including the surviving spouse, where "the disposition of the deceased's estate effected by his will or the law relating to intestacy, or the combination of his will and that law, is not such as to make reasonable financial provision for the applicant." Id. $\S 1$. In determining whether the testator has made a "reasonable provision" for the surviving spouse, an English court considers such statutorily prescribed factors as the nature of the decedent's estate, the surviving spouse's personal wealth, and the conduct of the surviving spouse toward the testator. See id. $\S 3$. Although some commentators have advocated the adoption of this system in the United States, see, e.g., Laufer, Flexible Restraints on Testamentary Freedom-A Report on Decedents' Family Maintenance Legislation, 69 HARv. L. Rev. 277, 277, 312-14 (1955); Plager, The Spouse's Nonbarrable Share: A Solution in Search of a Problem, 33 U. CH. L. REv. $681,682-83,714-15$ (1966), nothing in section 2-301 authorizes courts to consider equitable factors.

${ }^{80}$ See supra notes 30-47 and accompanying text.

${ }^{\text {Bo }}$ See supra notes $48-58$ and accompanying text.

B1 U.P.C. \$ 2-301(a).

${ }^{62}$ In Estate of Ganier, 402 So. $2 d 418$ (Fla. Dist. Ct. App. 1981), rev'd sub nom. Estate of Ganier v. Estate of Ganier, 418 So. $2 d 256$ (Fla. 1982), the court adopted this interpretation of section 2-301. See supra notes 33-40 and accompanying text. A few courts have interpreted other omitted-spouse statutes in a similar manner. See supra notes 26-28 and accompanying text. 
because it neglects any consideration of the testator's intent in making the devise, contrary to the stated underlying purposes of the Code. ${ }^{63}$ Section 1-102 indicates that the Code should be interpreted so as "to discover and make effective the intent of a decedent in distribution of his property";"64 and section 2-603, a general rule of construction covering intestate succession and wills, also notes that " $[t]$ he intention of a testator as expressed in his will controls the legal effect of his dispositions." pose, a literal interpretation of section 2-301 would only make sense if the drafters had consciously decided that any gift, however trivial, would suffice to bar the spouse's petition. Had the drafters of section 2-301 intended this result, however, they would have used a less ambiguous term than "provided for."

It is more likely that the drafters designed section 2-301 to address the common problem of an "unthinking" testator: a testator who executes a will that does not mention his surviving spouse, then marries and forgets to change his will before his death. Section 2-301 is designed to effect what the testator probably would have done had he considered the problem created by his marriage after the execution of his will. The commentary to section 2-301 emphasizes this purpose: the surviving spouse is entitled to the intestate share because this is "what the decedent would want the spouse to have if he had thought about the relationship of his old

63 Because the Code is "a general act intended as a unified coverage of its subject matter," U.P.C. § 1-105, and should "be liberally construed and applied to promote its underlying purposes and policies," id. $\S 1-102(a)$, specific sections should be analyzed within the context of the Code as a whole.

Br Id. § 1-102(b)(2). Section 1-102(b) also identifies four other basic purposes of the Code: (1) "to simplify and clarify the law concerning the affairs of decedents, missing persons, protected persons, minors and incapacitated persons"; (2) "to promote a speedy and efficient system for liquidating the estate of the decedent and making distribution to his successors"; (3) "to facilitate use and enforcement of certain trusts"; and (4) "to make uniform the law among the various jurisdictions." Id. § 1-102(b)(1), (3)-(5).

os Id. § 2.603 .

68 It should not be shocking that the drafters of section 2-301 failed to consider "mention cases." It is unrealistic to attribute omniscience to the drafters of statutes: statutes are intended to deal with general problems and cannot be expected to anticipate and resolve every possible problem that could arise in their application. See, e.g., United States v. Little Lake Misere Land Co., 412 U.S. 580, 593 (1973) ("inevitable incompleteness presented by all legislation"); Posner, Statutory Interpretation-in the Classroom and in the Courtroom, 50 U. CHI. L. Rev. 800, 811-12 (1983) (imputing omniscience to legislatures is an "unrealistic assumption" because "a statute necessarily is drafted in advance of, and with imperfect appreciation for the problems that will be encountered in, its application"); Note, Intent, Clear Statements, and the Common Law: Statutory Interpretation in the Supreme Court, 95 HaRv. L. REv. 892, 899 (1982) ("Congress' vision is not broad enough to consider all the details of each general policy it enacts .....") (footnote omitted). 
will to the new situation."67 Section 2-301 implements the testator's probable intent by presuming that the testator would have wanted the surviving spouse to receive the intestate share if the marriage occurred after the execution of a will that "fail[ed] to provide for" the spouse. ${ }^{68}$ The section provides, however, that this presumption yields to the testator's actual contrary intent when the testator either (1) indicates in his will that his omission of his surviving spouse was intentional or (2) makes inter vivos transfers to his surviving spouse that were intended to be in lieu of a provision in the will. ${ }^{69}$ Read as a whole, the section's presumption is that a testator who makes a will, later marries, and then dies without having either expressly disinherited his spouse or made an extratestamentary provision both did not think "about the relationship of his old will to the new situation" and would have wanted his spouse to have the intestate share if he had thought about his will in light of the new situation.

${ }^{62}$ U.P.C. § 2-301 comment.

68 Id. § 2-301(a).

${ }^{69}$ Id. As it is written, section 2-301 does unnecessarily defeat the testator's intent in one class "of cases: where extrinsic evidence could show that the testator intended not to make any provision for his surviving spouse, but he failed to indicate that fact in the antenuptial will and did not make any inter vivos gifts in lieu of a testamentary provision. See Gaubatz, Notes Toward a Truly Modern Wills Act, 31 U. Mrami L. Rev. 497, 552 (1977) (noting this exception). Section 2-301 operates when a testator "fails to provide for" his surviving spouse in his antenuptial will. When there is no mention of the surviving spouse in the antenuptial will, the use of the term "fails to provide for" is not ambiguous: it allows no other interpretation than that the spouse has been omitted.

Although the language of section 2-301 defeats the intent of "purposeful" omitting testators, it is not clear that this reflects the drafters' deliberate choice of the appropriate treatment for this class: the commentary indicates that the drafters had in mind unthinking, not purposeful, omitting testators, see supra notes $66-68$ and accompanying text. The drafters may have considered purposeful omissions a de minimis category, not worth addressing specifically, or they may not have addressed this problem at all when drafting the provision. It is useless to speculate at any length about the drafters' views because although their intent may be unclear, the language of the statute is not.

That section 2-301 defeats testamentary intent in purposeful-omission cases does not impugn the correctness of the testamentary-intent approach to "mention cases." Mention cases cannot be lumped in with purposeful-omission cases because the section's language does not clearly provide for the proper treatment of mention cases. Because the term "provide" is ambiguous, and could mean simple inclusion or something more substantial, see Webster's Third New InTERnational Dictionary 1827 (unabr. ed. 1976) (the word "provide" is defined as "to make a proviso or stipulation," or "to supply what is needed for sustenance or support"), mention cases are not clearly handled by the statute. That being the case, this comment argues that a testamentary-intent standard better reflects the overall purposes of the U.P.C., see infra notes 70-79 and accompanying text, and is in harmony with the drafters' view that the testator unintentionally omitted the spouse, see supra notes 66-68 and accompanying text. 
The "plain meaning" interpretation, ${ }^{70}$ however, presumes that decedent spouses of mentioned survivors have thought about the relationship of the old will to the new situation. This interpretation would defeat the purpose of section 2-301 by creating a per se rule that a petitioner may never be granted an intestate share of the estate if the antenuptial will contains a devise (however small) to him. For example, suppose that $T$ executed a will devising a small sum to his close friend $S$. Several years later, $T$ marries $S$ and dies without revising his will or considering the effect of his marriage on his old will. In this case, $T$ indicated neither that he intended $S$ to receive the devise in his old will once the couple married nor that he had even considered the effect that his subsequent marriage might have on his old will. Yet the "plain meaning" approach would prevent the application of section 2-301 in this situation. This result is inconsistent with the purpose of section 2-301 because that provision is designed to award an intestate share whenever the testator fails to consider the relationship between his marriage and his old will. Section 2-301 is not a rule of law intended to defeat the intent of a decedent, but is instead a subsidiary rule of construction designed to fill a gap in the antenuptial will.

The gap-filling nature of section 2-301 suggests an alternative interpretation of the provision, one consistent with both its purpose and text. A testator cannot have "fail[ed] to provide by will for his surviving spouse" if, after the marriage, he intended his survivor to receive only what was devised in his will. If this can be proved to be the case, the testator's intent is clear, and section 2301 , a subsidiary rule of construction designed to effectuate the testator's probable intent, should not be used to defeat his actual intent. If, on the other hand, the testator simply has not considered the relationship between his marriage and his will, the fact that he executed a will containing a devise to his future spouse should not prevent an award of the intestate share under section 2301 . The proper inquiry in cases where the testator marries a beneficiary of his will, then, is whether the testator thought about the relationship between his marriage and his will and intended his surviving spouse to receive the devise in his will. ${ }^{11}$

70 See supra notes 61-62 and accompanying text.

72 One commentator has argued that section 2-301 is intended to apply only if the testator has not expressed a contrary intent, see Comment, supra note 23, at 867-68, but the commentator failed to grasp the implications of this conclusion. Instead of recognizing that section 2-301 is a gap-filling mechanism that should not be construed to defeat the 
This "testator's intent" test is superior to the contemplationof-marriage ${ }^{72}$ and equivocal-intent ${ }^{73}$ approaches because it avoids defeating the testator's actual intent in an important class of cases. Although all three approaches reach the same result where the devise in the antenuptial will was executed in contemplation of marriage, ${ }^{74}$ the testator's-intent approach may reach a different result where it can be shown that, though the testator did not execute his will in contemplation of marriage, he later reexamined his will and decided not to revise it. To illustrate this point, suppose that $T$ and $S$ have been close friends since 1970. In 1975, $T$ executes a will devising a small sum of money to $S$ and the residue of his estate to his children by a prior marriage. At the time of the execution of his will, $T$ and $S$ had not discussed marriage, but four years later they decide to marry. After his marriage, $T$ does not revise his will or make any substantial inter vivos transfers to $S$. When his accountant asks him if he has thought about revising his will, he tells the accountant that he believes that the devise in his will adequately provides for $S$ and that he wants his children to receive the bulk of his estate. $T$ dies in 1983, and $S$ petitions for the intestate share under section $2-301 .^{75}$

In this case, the testator's-intent approach will reach a different result from those that would be reached under either the contemplation-of-marriage test or the equivocal-intent test. Since $T$ had not executed his will in contemplation of marriage to' $S$, the

testator's intent, the commentator advocated the adoption of the equivocal-intent approach of the Utah Supreme Court, see id. at 868-75, which may defeat the testator's intent in an important class of cases. See infra notes 74-76 and accompanying text.

72 See supra notes 30-47 and accompanying text.

73 See supra notes $48-58$ and accompanying text.

${ }^{74}$ Under the contemplation-of-marriage approach, only a devise proved to have been executed in contemplation of marriage can prevent the application of section $2-301$. In this situation, the equivocal-intent and testator's-intent approaches also prevent the surviving spouse from taking an intestate share under section 2-301: a devise executed in contemplation of marriage establishes that the testator intended for his surviving spouse to receive the devise.

${ }^{76}$ Particularly in the case of a second marriage, a testator is likely to devise to his surviving spouse a relatively small amount and give the bulk of the estate to children by a previous marriage or to other relatives. See J. Dukeminier \& S. Johanson, Family Wealth Transactions: Wills, Trusts, and Estates 535-36 (2d ed. 1978). The application of section 2-301 in this situation will often, contrary to the testator's intent, either prevent the other devisees from receiving anything or will reduce their shares (because the application of section 2-301 makes the spouse the primary beneficiary). This may have been the case in Estate of Ganier v. Estate of Ganier, 418 So. 2d 256 (Fla. 1982), and Estate of Christensen v. Christensen, 655 P.2d 646 (Utah 1982), but it is impossible to know because the supreme courts of Florida and Utah failed to inquire whether the testator, after the marriage, intended his surviving spouse to receive the devise in his will. 
contemplation-of-marriage test will allow $S$ to receive an intestate share under section 2-301. The equivocal-intent approach would also allow an intestate-share award because (1) the dollar value of the devise to $S$ is small in both absolute terms and compared with what $T$ 's children will receive; (2) the will was executed four years before the marriage; (3) the marriage lasted for four years; and (4) $T$ did not make any substantial inter vivos gifts to $S .{ }^{76}$ Under the testator's-intent standard, however, $S$ is not entitled to the intestate share: $T$ had considered the relationship between his antenuptial will and his marriage and intended for $S$ to receive what was devised in the will.

In this hypothetical, the testator clearly intended for his surviving spouse to receive only the devise in his will, yet the contemplation-of-marriage and equivocal-intent approaches ignore his intent and give the intestate share to the surviving spouse. This result only makes sense if section $2-301$ is, at least in part, intended to protect the surviving spouse. The purpose of that section, however, is to implement the testator's probable intent, not to frustrate the testator's intent by protecting the surviving spouse. ${ }^{77}$ Moreover, spousal protection, unlike implementation of the testator's intent, ${ }^{78}$ is not a basic purpose of the Code. ${ }^{79}$ Hence, section 2-301 should not be construed to protect the surviving spouse when that goal conflicts with the testator's intent.

A refusal to adopt either the equivocal-intent test or the contemplation-of-marriage requirement in applying section 2-301 does not mean that the interest in spousal protection cannot be satisfied. A surviving spouse who does not receive the intestate share under section 2-301 may either take the testamentary devise or renounce that devise and take an elective share under section 2$201,{ }^{80}$ which gives a surviving spouse a share in the decedent's estate regardless of the testator's intent. The commentary to the elective-share provisions expressly states that their purpose is "to protect a spouse of a decedent who was a domiciliary against donative transfers by will and will substitutes which would deprive the

${ }^{28}$ For a discussion of the factors considered under the equivocal-intent approach, see supra notes 57-58.

77 See supra notes 67-71 and accompanying text.

78 See supra notes 63-65 and accompanying text.

70 The Code provides for the protection of the surviving spouse in special elective-share provisions. See infra notes 80-81 and accompanying text.

so U.P.C. $\$ 2-201$. For a discussion of the Code's elective-share provisions, see supra note 5 . 
survivor of a 'fair share' of the decedent's estate."81 Since the Code contains a separate provision specifically designed to protect surviving spouses, it is unnecessary to protect them-at the expense of the testator's intent-either by applying section 2-301 to all surviving spouses who were not provided for by devises executed in contemplation of marriage or by engaging in an inquiry into whether the surviving spouse "deserved" the intestate share.

\section{Application of the Testator's-Intent Standard}

Because testamentary intent is the key to section 2-301, the will should stand even if the testator did not contemplate marriage when making the will, so long as he later exhibited an intention that his will remain intact despite the intervening marriage. In order to decide whether this is the case, a court must determine (1) whether the testator did think about the "relationship of his old will to the new situation," and (2) whether he wished his will to remain intact. The proper application of the testator's-intent approach requires appropriate standards for allocating the burden of proof and for the admission of extrinsic evidence bearing on the testator's intent.

\section{A. Allocation of the Burden of Proof}

Omitted-spouse statutes similar to section 2-301 have generally been interpreted so as to place the burden of proof on the proponent of the will, not on the surviving spouse who received a devise in the will. ${ }^{82}$ One rationale for placing the burden of proof on the proponent of the will rests on the assumption that the primary purpose of omitted-spouse statutes is the protection of the surviving spouse. In order to protect the surviving spouse, courts have required the proponent of the will to prove the existence of one of the exceptions to revocation under the omitted-spouse statute. ${ }^{83}$

${ }^{81}$ U.P.C. art. II, pt. 2 general comment.

${ }^{82}$ See, e.g., Estate of Duke, 41 Cal. 2d 509, 512, 261 P.2d 235, 237 (1953); In re Snopek's Estate, 249 A.D. 396, 398, 292 N.Y.S. 359, 362 (1937), aff'd sub nom. In re Gross, 275 N.Y. 606, 11 N.E.2d 778 (1938); see also 79 AM. Jur. 2D Wills § 603 (1975) ("The burden of proof of acts invoking an exception to the rule of revocation by operation of law rests upon him who asserts the exception."). But see In re Estate of Livingston, 172 So. 2d 619, 620 (Fla. Dist. Ct. App. 1965) (because "provision by will" exception is "evident upon the face of the will itself," mentioned spouse has the "burden of alleging and proving that such will failed to provide for [him] as contemplated by [the statute]").

${ }_{33}$ See, e.g., Estate of Duke, 41 Cal. 2d 509, 512, 261 P.2d 235, 237 (1953); In re Estate of Paul, 29 Cal. App. 3d 690, 696-97, 105 Cal. Rptr. 742, 747 (1972). Examples of the statutory exceptions to revocation include: (1) an express provision in the antenuptial will that it 
Moreover, since these omitted-spouse statutes create a presumption that the will should be revoked when the surviving spouse marries the testator after the execution of his will, ${ }^{84}$ the courts have reasoned that the proponent of the will should have the burden of proving that the will should not be revoked.8s

The supreme courts of Utah and Florida, however, have held that section 2-301 places the burden of proof on the surviving spouse who was mentioned in the antenuptial will. ${ }^{86}$ Several arguments support their allocation of the burden of proof. First, because the purpose of section 2-301 is not to protect the surviving spouse but rather to implement the testator's probable intent where he has not considered the problem created by his marriage after the execution of his will, ${ }^{87}$ it is unnecessary to place the burden of proof on the proponent of the will in order to protect the surviving spouse. Moreover, unlike omitted-spouse statutes that create a presumption of revocation where the surviving spouse shows that he married the testator after the execution of the latter's will, ${ }^{88}$ section $2-301$ creates a presumption that a surviving spouse should receive the intestate share only when he married the testator after the latter's will was executed and when that will "fails to provide for" the surviving spouse. ${ }^{80}$ This suggests that in addition to establishing that he married the testator after the execution of the latter's will, the surviving spouse should have to prove that the antenuptial "will did not "provide for" him.

Finally, section 3-407 of the Code provides that the contestants of a properly executed will have the burden of proving its revocation. ${ }^{90}$ This provision reflects the general rule that where the will has been properly executed, courts will presume that it accurately embodies the testator's intent and will put the burden of

was made in contemplation of marriage, e.g., GA. Code ANN. § 53-2-76 (1982); (2) an agreement by the spouse to waive any share in the testator's estate, e.g., CAL. ProB. Code $\$ 6561$ (West Supp. 1985); and (3) mention of the surviving spouse in the will in such a way as to show that the omission of the spouse was intentional, e.g., WASH. REV. CODE ANN. § 11.12.050 (West 1967).

84 See, e.g., Cal. Prob. Code § 6560 (West Supp. 1985); N.Y. Dec. Est. Law § 35 (McKinney 1919) (repealed 1967).

ss See, e.g., Estate of Duke, 41 Cal. 2d 509, 512, 261 P.2d 235, 237 (1953); In re Snopek's Estate, 249 A.D. 396, 398, 292 N.Y.S. 359, 362 (1937), aff'd sub nom. In re Gross, 275 N.Y. 606, 11 N.E.2d 778 (1938).

so See Estate of Ganier v. Estate of Ganier, 418 So. 2d 256, 260 (Fla. 1982); Estate of Christensen v. Christensen, 655 P.2d 646, 650 (Utah 1982).

${ }^{87}$ See supra notes 67-71 and accompanying text.

ss See supra note 84 .

s9 U.P.C. § 2-301(a).

so Id. § 3-407. 
showing otherwise on the party contesting the will. ${ }^{91}$ Although section 2-301 does not expressly refer to a revocation of the antenuptial will, it does in effect operate as a partial revocation of the will: ${ }^{22}$ accordingly, the rationale underlying section $3-407$ - that the contestants of a properly executed will should have the burden of establishing that it does not embody the testator's intent-requires allocation of the burden of proof to the surviving spouse.

Placing the burden of proof on the surviving spouse has two consequences. First, a surviving spouse who received a devise in the antenuptial will bears the burden of persuading the trier of fact that the antenuptial will did not "provide for" him within the meaning of section 2-301. ${ }^{93}$ Second, and more important, a surviving spouse bears the burden of producing evidence that the antenuptial will failed to provide for him..$^{94}$ If the antenuptial will does not contain a devise to the surviving spouse, the surviving spouse has established a prima facie case that he was not provided for in the will, and the burden of production shifts to the proponent of the will. When the antenuptial will does contain a devise to the surviving spouse, however, the surviving spouse will have to produce evidence that the will does not "provide for" him. If the surviving spouse presents evidence that the testator did not execute the antenuptial will in contemplation of marriage, this evidence, if believed, would establish a factual probability that the will did not

91 See, e.g., Langbein, Substantial Compliance with the Wills Act, 88 HARv. L. REv. 489, 513 (1975) ("Proper compliance with the Wills Act, so-called due execution, is the basis in modern law for certain presumptions which shift the burden of proof from the proponents of a will to any contestants.").

92 The language of section 2-301 merely provides that "the omitted spouse shall receive the [intestate share]," U.P.C. \$ 2-301(a), and does not expressly label this as a revocation of the testator's will. One might consider the operation of section 2-301 not to be a revocation because section 2-508 provides that "divorce or annulment revokes any disposition or appointment of property made by the will to the former spouse" and that "[n]o change of circumstances other than as described in this section revokes a will." Id. $\S 2-508$. The commentary to section 2-508, however, suggests that the restriction of revocation to divorce or annulment was intended only "to change the rule in some states that subsequent marriage or marriage plus birth of issue operate to revoke a will" (i.e., the old rule of total revocation) and was not intended to determine who should bear the burden of proof under section 2301. Id. comment. Whatever the drafters chose to call section 2-301, it does operate as a partial revocation. See J. Dukeminier \& S. Johanson, supra note 7, at 399 (section 2-301 "in effect permits a partial revocation of a will because of a change in circumstances").

93 U.P.C. § 3-407 ("Parties have the ultimate burden of persuasion as to matters with respect to which they have the initial burden of proof.").

94 See Edward Cleary, McCormick on Evidence § 337, at 951-52 (3d ed. 1984) (initial burden of producing evidence is usually assigned to the party who bears the burden of persuasion). 
"provide for" him within the meaning of the statute..$^{95}$ At that point, the burden of production shifts to the proponent of the will to show either that the devise actually was executed in contemplation of marriage or that, though the parties had not contemplated marriage when the will was executed, the testator reexamined the will after his marriage and intended it to remain intact.

\section{B. Admissibility of Extrinsic Evidence}

The allocation of the burden of proof to the surviving spouse will determine the outcome of many cases in which the testator marries a beneficiary of his will: the surviving spouse will be unable to produce evidence rebutting the presumption that the devise in the antenuptial will "provide[s] for" him, by showing that it was not executed in contemplation of marriage. If such evidence is produced, however, it may be necessary to admit extrinsic evidence to determine whether the testator had later considered the relationship of his old will to the new situation and intended his spouse to receive only the devise in his antenuptial will. For example, a surviving spouse may want to establish that the devise in the will was not executed in contemplation of marriage by showing that he and the testator had not discussed marriage until long after the will was executed. ${ }^{.6} \mathrm{~A}$ proponent of the will, on the other hand, may want to introduce evidence that the testator, after his marriage, had told his accountant that he wanted his spouse to receive only the devise in his antenuptial will. In such cases, a court must examine extrinsic evidence in order to ascertain the testator's intent.

There are two main types of extrinsic evidence: (1) evidence of facts and circumstances extrinsic to the will; and (2) the testator's direct declarations of intent. ${ }^{97}$ At early common law, extrinsic evi-

os The vast majority of omitted-spouse situations probably involve "unthinking testators" (that class with whom the drafters of section 2-301 were concerned, see supra text following note 66) rather than testators who think about the situation and decide that they are satisfied with the original will as it stands. The contemplation-of-marriage approach also presumes that most "mention cases" where the will was not executed in contemplation of marriage are caused by an "unthinking testator": when a testator makes a will that includes a devise to someone with whom he does not then contemplate marriage, it is more likely than not that the testator would revise the will after marrying that person if he thought about the relationship of the old will to the new situation. The presumption is made irrebuttable, however, when that approach excludes extrinsic evidence about events occurring after the execution of the will that would show that the presumption was erroneous in this case. This leads to the defeat of the testator's intent in such cases.

of See, e.g., Estate of Ganier v. Estate of Ganier, 418 So. 2d 256, 260 (Fla. 1982).

97 See, e.g., T. ATKINSON, supra note $3, \S 146$, at 810 (distinguishing between the testator's direct declarations of intent and other forms of extrinsic evidence); M. RHEINSTEIN \& 
dence could not be admitted to alter or vary the terms of a will, ${ }^{98}$ but courts soon created exceptions to this no-extrinsic-evidence rule. ${ }^{98}$ At present, the general rule is that a party may introduce evidence of extrinsic facts and circumstances (but usually not the testator's direct declarations of intent ${ }^{100}$ ) in order to place the court "in the armchair of the testator" 101 or to cure an ambiguity in the will. ${ }^{102}$ For example, a testator may misdescribe a piece of

M. Glendon, supra note 1, at 357-58 (same).

${ }^{98}$ After the enactment of the Statute of Wills, 32 Hen. 8, ch. 1 (1540), which allowed the testamentary disposition of real property in certain circumstances, the courts initially refused to admit extrinsic evidence to alter the terms of the will. See, e.g., Challoner's \& Bowyer's Case, 2 Leon. 70, 70, 74 Eng. Rep. 366, 366 (C.P. 1587); Brett v. Rigden, 1 Plowd. 340, 345, 75 Eng. Rep. 516, 525 (Q.B. 1568); see also James Thayer, A Preliminary Treatise on Evidence at the Common Law 396, 414-15 (1898); 9 John Wigmore, A Treatise on THE ANGlo-American System of Evidence § 2470, at 224-25 (3d ed. 1940).

90 See J. ThAYER, supra note 98, at 414-49 (describing the development of exceptions to the no-extrinsic-evidence rule); 9 J. WIGMORE, supra note $98, \S 2470$, at 225-28 (same).

${ }^{100}$ See, e.g., T. AtKInson, supra note $3, \S \S 60,146$, at $286-88,810 ; 4$ W. Bowe \& D. PARKER, supra note $2, \S \S 32.8,32.9$, at 259-60, 266-70; 9 J. Wigmore, supra note $98, \S 2471$. An exception to the general rule has been created where the will contains an equivocation, a term that applies equally to two or more persons or objects. See, e.g., T. ATkINSoN, supra note $3, \S 60$, at $287 ; 4$ W. Bowe \& D. PARKER, supra note 2 , 32.9 , at $270-71 ; 9$ J. Wigmore, supra note $98, \S 2472$, at 233 . For example, a testator may have devised $\$ 40,000$ to "my nephew Joe" when he had two nephews with that name. In this case, the testator's direct declarations of intent would be admissible to establish which nephew was intended to receive the devise. See, e.g., Money v. Money, 235 Ala. 15, 176 So. 817 (1937) (devise to "brothers children"); Tinker's Estate, 157 Misc. 200, 283 N.Y.S. I51 (Sur. Ct. 1935) (devise to a named hospital where two institutions with that name existed). In practice, an "equivocation" is virtually identical to a "latent ambiguity." See infra note 102. Accordingly, courts have generally admitted the testator's direct declarations of intent when the will contains a latent ambiguity. See, e.g., Virginia Nat'l Bank v. United States, 443 F.2d 1030, 1034 (4th Cir. 1971) (applying Virginia law); Breckner v. Prestwood, 600 S.W.2d 52, 56 (Mo. Ct. App. 1980). But see, e.g., In re Estate of Smith, 119 Ariz. 293, 296, 580 P.2d 754, 757 (1978) (allowing the admission of testator's direct declarations of intent to cure patent as well as latent ambiguities).

${ }^{101}$ In re Estate of Houston, $414 \mathrm{~Pa} .579,585,201$ A.2d 592, 595 (1964).

${ }^{102}$ See, e.g., R. Wellman, L. Waggoner \& O. Browder, supra note 14, at 383; 9 J. Wigmore, supra note 98, §§ 2470-2472; Langbein \& Waggoner, Reformation of Wills on the Ground of Mistake: Change of Direction in American Law?, 130 U. PA. L. REv. 521, 530 \& n.28 (1982). Latent ambiguities are not apparent upon the face of the will but only arise when the terms of the will are applied to extrinsic circumstances (e.g., a devise to "Indianapolis Home for the Aged located at $2007 \mathrm{~N}$. Capitol Avenue" when there are The Altenheim Home of Indianapolis at that address and The Indianapolis Home for the Aged, Inc., located at $1731 \mathrm{~N}$. Capitol Avenue). These have historically been distinguished from patent ambiguities, which appear upon the face of the will, as for example when provisions in the will conflict. See 4 W. BowE \& D. PARKER, supra note 2, § 32.7, at 254-55. This distinction can be traced back to Sir Francis Bacon, who argued that extrinsic evidence is not admissible to resolve a patent ambiguity: "[A patent ambiguity] is never holpen by averrement . . . because the law will not couple and mingle matter of specialty, which is of the higher account, with matter of averrement, which is of inferior account . ..." FrancIs BAcon, Elements of the Common Lawes of England 82 (London 1639). The distinction be- 
real estate in his will, so that when the will is probated it transpires that the testator did not own the land described in the will. In order to resolve the uncertainty arising from this situation, a court may admit evidence that the testator owned a similar parcel of land otherwise fitting the testamentary description and not devised to anyone else. ${ }^{103}$

The courts' primary objection to the admission of extrinsic evidence is that it would violate an important purpose of the Wills Act formalities of writing, signature, and attestation: ${ }^{104}$ to provide

tween latent and patent ambiguities has been criticized severely, see, e.g., 4 W. BowE \& D. PARKER, supra note $2, \S 32.7$, at 258 ("it undoubtedly would be a step forward in the development of our law to discard the distinction entirely"); J. THAYER, supra note 98, at 422-25, 471-73 (characterizing the distinction as an "unprofitable subtlety"); $9 \mathrm{~J}$. WiGMORE, supra note $98, \S 2472$, at 239 (criticizing it as "artificial"), and it probably has little effect today, see, e.g., R. Wellman, L. WAGgoner \& O. Browder, supra note 14, at 373-74; Langbein \& Waggoner, supra, at $530 \mathrm{n} .28$. To the extent that it is recognized at all, it probably prevents the admission of the testator's direct declarations of intent where there is a patent ambiguity. See supra note 100.

Courts have recently begun to relax the no-extrinsic-evidence rule. See Estate of Taff, 63 Cal. App. 3d 319, 324-25, 133 Cal. Rptr. 737, 740-41 (1976); Engle v. Siegel, 74 N.J. 287, 291, 377 A.2d 892, 894 (1977); cf. 9 J. WIGMORE, supra note 98, \$§ 2461-2462, 2470, at 18796, 224-28 (advocating the abandonment of the no-extrinsic-evidence rule). While purporting to construe wills, courts have allowed the liberal admission of extrinsic evidence, including the testator's direct declarations of intent. See, e.g., Taff, 63 Cal. App. 3d at 325, 133 Cal. Rptr. at 741; Engle, 74 N.J. at 295-96, 377 A.2d at 896. For discussions of these developments, see Langbein \& Waggoner, supra, at 555-62; Note, Ascertaining the Testator's Intent: Liberal Admission of Extrinsic Evidence, 22 HASTINGs L.J. 1349 (1971).

${ }^{103}$ See, e.g., Patch v. White, 117 U.S. 210 (1886) (where the will devised lot number six in square 403 , which the testator did not own, the Court admitted extrinsic evidence to establish that the testator had intended to devise lot number three in square 406); Arnheiter v. Arnheiter, 42 N.J. Super. 71, 125 A.2d 914 (1956) (similar); In re Will of Goldstein, 46 A.D.2d 449, 363 N.Y.S.2d 147 (1975) (similar), aff'd per curiam, 38 N.Y.2d 876, 382 N.Y.S.2d 743 (1976).

104 The various American statutes are largely derived from the Statute of Frauds, 29 Car. 2, ch. 3, $\$ 5$ (1677), which required devises of land to be in writing, signed by the testator, and witnessed, and from the superseding Statute of Victoria, $7 \mathrm{Wm} .4$ \& 1 Vic., ch. 26 (1837), which required that devises of real and personal property be in writing, signed by the testator at the end of the document, and attested by two witnesses in the presence of the testator. See T. AtKInson, supra note $3, \S 62$, at 292. Some states impose additional requirements, e.g., that the testator tell the witnesses that the instrument is his will, or that the witnesses sign in the presence of each other. See generally Kossow, supra note 5, at 1369-77 (describing the statutory formalities required in various jurisdictions). Most states have adopted statutes similar to the Statute of Frauds, see R. Wellman, L. Waggoner \& O. BrowDER, supra note 14 , at 129 , and more than a quarter of the states have enacted U.P.C. $\S 2-502$, which requires a "writing signed by the testator or in the testator's name by some other person in the testator's presence and by his direction," and the signatures of "at least 2 persons each of whom witnessed either the signing or the testator's acknowledgment of the signature or of the will," see 8 U.L.A. 1 (1983).

In addition to the evidentiary purpose, see infra note 105 and accompanying text, the Wills Act formalities serve three other functions: (1) to warn the testator of the seriousness and finality of a will; (2) to protect the testator against third parties who might seek to 
the court with reliable evidence of the testator's intent. ${ }^{105}$ Because a will is ambulatory, extrinsic evidence of the testator's intent can only be presented when the testator is no longer available to substantiate or refute it. As a result, the testator's main protection against mistaken or fraudulent evidence is judicial deference to a will executed in compliance with statutory formalities designed in part to ensure that the will accurately reflects the testator's intent. $^{108}$

The general rule excluding extrinsic evidence has usually been applied in cases involving a surviving spouse who received a devise in an antenuptial will. With the exception of the Utah Supreme Court, which admitted evidence of extrinsic facts and circumstances that arose after the execution of the will, ${ }^{107}$ most courts have only admitted evidence of extrinsic facts and circumstances existing at the time the will was executed or soon after if it helps explicate the testator's intent at execution. ${ }^{108}$

deceive or coerce him; and (3) to standardize wills. See Langbein, supra note 91, at 492-97; see also Gulliver \& Tilson, Classification of Gratuitous Transfers, 51 YALE L.J. 1, 5-13 (1941) (characterizing the purposes of the Wills Act in terms of the "ritual," "evidentiary," and "protective" functions).

105 See, e.g., 4 George Palmer, The Law of Restitution \& 20.1, at 157-58 (1978) ("If effect were given to extrinsic evidence of such different intentions, there would be a very real danger that the testimony would be fraudulent or at least mistaken. It is the very danger that brought about the enactment of that part of the statute of wills governing dispositions.") (footnotes omitted); Langbein, supra note 91, at 492 ("The primary purpose of the Wills Act has always been to provide the court with reliable evidence of testamentary intent."). Because extrinsic evidence has been admitted in a wide variety of circumstances, see, e.g., Langbein \& Waggoner, supra note 102, at 529-54 (discussing the various exceptions to the no-extrinsic-evidence rule), some commentators have suggested that the real objection to its admission is its technical noncompliance with the Wills Act. See id. at 522-23, $528-29,566-77$; id. at 555 ("When the circumstances are such that mistake can be remedied without overtly supplementing the attested language of a will, the courts have confidently admitted and evaluated extrinsic evidence of mistake .... The real barrier to a general reformation doctrine for mistaken wills has not been the evidentiary problem . . . but the problem of achieving technical compliance with the Wills Act.").

${ }^{108}$ See, e.g., R. WELlman, L. Waggoner \& O. Browder, supra note 14, at 367; Langbein, supra note 91 , at 492.

${ }^{107}$ Estate of Christensen v. Christensen, 655 P.2d 646, 650 (Utah 1982) (discussed supra notes 48-58 and accompanying text).

${ }^{108}$ See, e.g., Estate of Ganier v. Estate of Ganier, 418 So. 2d 256, 260 (Fla. 1982); In re Estate of Day, 7 Ill. 2d 348, 354-55, 131 N.E.2d 50, 53 (1955); cf. In re Estate of Bent, 142 Misc. 811, 813-14, 255 N.Y.S. 538, 541-42 (Sur. Ct. 1932) (evidence of extrinsic facts and circumstances is admissible when the will refers to the surviving spouse by name but not when it refers to him in a different status such as "my friend"). But see Estate of Poisl, 44 Cal. 2d 147, 150, 280 P.2d 789, 792 (1955) (extrinsic evidence is not admissible where the antenuptial will contains a devise to the surviving spouse). Recent developments in California may have reduced the significance of the court's refusal in Poisl to admit extrinsic evidence. See supra note 102. 
Limiting the admissible evidence to extrinsic facts and circumstances existing at the time of execution of the will, ${ }^{108}$ however, will sometimes result in the grant of the intestate share under section 2-301 even though the testator intended his surviving spouse to receive only the devise in his will. ${ }^{110}$ Such a limitation would preclude, for example, evidence that the testator reexamined his will after his marriage and did not change it, even though such evidence would indicate that the testator had considered the relationship between his marriage and his will and that he wanted his surviving spouse to receive only what was devised in the will. More important, the general rule prevents the admission of the testator's direct declarations of intent, which are even more likely than extrinsic facts and circumstances to indicate what the testator intended. ${ }^{11}$ For example, evidence that, after his marriage, the testator told his accountant that his will already provided for his surviving spouse and that he therefore did not intend to revise his will would clearly indicate that he had intended his testamentary scheme to remain intact after his marriage.

To the extent that the admission of extrinsic evidence presents a danger of mistaken or fabricated testimony, this problem can be handled by the creation of appropriate evidentiary safeguards. ${ }^{112}$ First, in determining whether the testator intended his surviving spouse to receive the devise in his will, courts should

100 Commentators have disagreed about the usefulness of evidence of extrinsic facts and circumstances that arose subsequent to the execution of the will. Compare McGovern, Facts and Rules in the Construction of Wills, 26 UCLA L. REv. 285, 286 (1978) (arguing that such evidence is "often [a] more reliable guide[] to intent than the words used in the will"), with 4 W. BOWE \& D. PARKER, supra note $2, \S 30.8$ ("[s]ubsequent events cannot be considered").

${ }^{130}$ Section 2-301 is a subsidiary rule of construction and should not be applied when the testator intends the spouse to receive only the devise in the will. See supra notes 67-71 and accompanying text.

${ }^{111}$ See, e.g., 9 J. Wigmore, supra note $98, \S 2471$, at 229 (testator's direct declarations of intent are useful in determining his intent). Moreover, admission of extrinsic evidence of the testator's intent in these circumstances does not pose the danger of remaking the will contrary to the testator's intent because the purpose of the admission is to uphold the will by avoiding a statutory rule of implied revocation. See id. $\$ 2475$, at $248-49$ ("the ascertainment of the actual intent ...., including the testator's circumstances and declarations ... has long been the practice in dealing with the artificial rules of presumption as to . . revocation of a will by marriage, and it is capable of application to any general and artificial rule of inference") (footnotes omitted) (emphasis in original).

112 In advocating a reformation doctrine for mistakes in wills, two commentators have suggested that procedural safeguards would adequately address the evidentiary concerns present in the admission of extrinsic evidence when the testator cannot confirm or deny the evidence. Langbein \& Waggoner, supra note 102, at 577-79. They proposed that extrinsic evidence should be admitted to reform a mistake in a will where the error (1) affected a material provision in the will; (2) involves a fact or event of particularity; and (3) satisfies the clear-and-convincing-evidence standard. See id. 
admit extrinsic evidence under a clear-and-convincing-evidence standard of proof. ${ }^{113}$ This standard addresses the same evidentiary concerns that prompted the creation of the no-extrinsic-evidence rule (by testing extrinsic evidence against an exceptionally high standard of proof), but it avoids preventing the admission of reliable evidence of the testator's intent. ${ }^{114}$ Second, extrinsic evidence should be admitted only if it is relevant to the key inquiries: (1) whether the testator considered the "relationship of his old will to the new situation," 115 and (2) whether he intended his surviving spouse to receive only what was devised in the antenuptial will. This limitation would help reduce the danger of abuse that is present whenever interested parties testify.

Section 2-301 itself supports the admission of extrinsic evidence of the testator's intent. In order to determine whether a testator intended inter vivos transfers to replace a testamentary provision, section 2-301 provides that the testator's intent may be "shown by statements of the testator or from the amount of the transfer or other evidence." "16 The Code's refusal to adhere to the no-extrinsic-evidence rule in this case suggests that extrinsic evidence should also be admitted in the closely related case (that the drafters overlooked) where the testator marries a beneficiary of his antenuptial will.

A more liberal admission of extrinsic evidence will not greatly increase the burden on probate courts or unduly delay the probate of estates. The high standard of proof and the limited nature of the inquiry will deter surviving spouses from bringing spurious actions and proponents of wills from contesting genuine claims. ${ }^{117}$

113 The clear-and-convincing-evidence standard has frequently been applied where there is a danger that extrinsic evidence may be fraudulent or mistaken. See E. CLEary, supra note $94, \S 340$, at $960-61$. For example, courts have admitted and tested extrinsic evidence of mistake in inter vivos transfers against this standard. See Langbein \& Waggoner, supra note 102, at 525-26; Palmer, Reformation and the Parol Evidence Rule, 65 Mich. L. REv. 833, 847 (1967). This test has worked well in the case of inter vivos transfers because the courts have enforced it vigorously. See, e.g., In re Estate of Duncan, $426 \mathrm{~Pa}$. 283, 293-94, 232 A.2d 717, 722-23 (1967) (reversing lower court that allowed reformation of instrument amending inter vivos trust because evidence of mistake was not clear and convincing); In re Estate of LaRocca, 411 Pa. 633, 643, 192 A.2d 409, 414 (1963) (similar).

114 Although the clear-and-convincing-evidence standard cannot be defined with precision, it falls between the preponderance-of-the-evidence test normally used in civil litigation and the beyond-reasonable-doubt rule in criminal law. See E. ClEARY, supra note 94 , §§ 339 341 (describing the weight of evidence necessary to meet each standard).

116 U.P.C. § 2-301 comment.

116 Id. § 2-301(a).

${ }^{117}$ Cf. Langbein \& Waggoner, supra note 102, at 586 (adoption of a reformation doctrine that allows the admission of extrinsic evidence will not increase the amount of strike- 
Moreover, the allocation of the burden of proof to the surviving spouse will dispose of most "mention cases" without an extensive factual inquiry. More restrictive rules of evidence than those proposed in this comment would simplify and expedite probate administration of "mention cases," but only at the cost of defeating the testator's intent, the very purpose that section $2-301$ is intended to promote.

\section{CONCLUSION}

This comment has examined the problem of whether a surviving spouse who received a devise in an antenuptial will has been "provided for" within the meaning of section 2-301. Because section 2-301 is a rule of construction designed to operate only when the testator has failed to consider changed circumstances (not a rule of law that operates regardless of the testator's intent), the proper inquiry in cases where a testator marries a beneficiary of his will is whether the testator continued to intend that his surviving spouse receive only what was devised in his antenuptial will. To implement this approach and to minimize evidentiary concerns and administrative difficulties, the burden of proof should be allocated to the surviving spouse, and extrinsic evidence should be admitted, under a clear-and-convincing evidence standard, when it is relevant to the inquiry into the testator's intent.

Mary Ellen Kazimer 